STUDI

FRANCESI
Studi Francesi

Rivista quadrimestrale fondata da Franco Simone

177 (LIX | III) | 2015

Varia

\title{
La faute dans l'épopée médiévale. Ambiguité du jugement, sous la direction de Bernard Ribémont
}

\section{Walter Meliga}

\section{(2) OpenEdition}

\section{Journals}

\section{Edizione digitale}

URL: http://journals.openedition.org/studifrancesi/1235

DOI: $10.4000 /$ studifrancesi. 1235

ISSN: 2421-5856

\section{Editore}

Rosenberg \& Sellier

\section{Edizione cartacea}

Data di pubblicazione: 1 décembre 2015

Paginazione: $561-562$

ISSN: 0039-2944

\section{Notizia bibliografica digitale}

Walter Meliga, «La faute dans l'épopée médiévale. Ambiguïté du jugement, sous la direction de Bernard Ribémont», Studi Francesi [Online], 177 (LIX | III) | 2015, online dal 01 décembre 2015, consultato il 06 janvier 2021. URL: http://journals.openedition.org/studifrancesi/1235; DOI: https://doi.org/10.4000/ studifrancesi.1235

Questo documento è stato generato automaticamente il 6 janvier 2021.

\section{(c)}

Studi Francesi è distribuita con Licenza Creative Commons Attribuzione - Non commerciale - Non opere derivate 4.0 Internazionale. 


\title{
La faute dans l'épopée médiévale. Ambiguité du jugement, sous la direction de Bernard Ribémont
}

\author{
Walter Meliga
}

\section{NOTIZIA}

La faute dans l'épopée médiévale. Ambiguitté du jugement, sous la direction de Bernard RIBÉMONT, Rennes, Presses Universitaires de Rennes, 2012 («Interférences»), pp. 254.

1 Il volume (che raccoglie gli atti di un colloquio del 2010 sull'argomento) affronta la questione della colpa all'interno dell'epica francese - con presenza anche di quelle latina e occitana - pur nel quadro definito dalla dominante visione cristiana e dalla netta separazione morale fra le parti che i testi ci presentano in lotta fra di loro. L'introduzione di Bernard RIBÉMONT (La faute épique, mesure et démesure) si interroga sul problema delle circostanze attenuanti della colpa e sugli apporti dei diritti romano, canonico e consuetudinario; considera poi la ben più complessa e articolata realtà dei testi letterati e in particolare delle chansons de geste; infine, prendendo spunto dai saggi pubblicati, rileva la presenza di una certa ambiguità nel trattamento della colpa, pur a fronte di un atteggiamento nettamente manicheo in materia morale, e di vari problemi connessi all'agire politico e personale, anche in relazione alla concezione cristiana del peccato. Gli interventi sono numerosi e suddivisi in tre parti: "Trahison et circonstances atténuantes», sul grande problema del tradimento in diversi testi (Renaud de Montauban, Daurel et Beton, Florence de Rome, Doon de la Roche) e sui personaggi delle donne saracene convertite; «Une culpabilité et une innocence qui se cherchent», sulla questione della colpevolezza (specialmente a proposito di Garin le Lorrain, Huon de Bordeaux, Chanson d'Antioche, Aquilon de Bavière e alcune chansons tarde); «La guerre, le héros et la mort», sulle condizioni ambigue della guerra epica e dell'eroe (Guglielmo d'Orange) e la relativizzazione della colpa nella morte e nel crimine. 
2 La raccolta è un bell'esempio di collaborazione fra analisi letteraria e ricerca sul diritto medievale e risulta di grande utilità agli studiosi dell'epica medievale come agli storici. 